\title{
NCAR under fire, a victim of its own success
}

Washington. The National Center for Atmospheric Research (NCAR) in Boulder, Colorado, may have become too successful for its own good. As scientists at the \$76million research centre win more outside grants, the US atmospheric research community has become concerned that NCAR is abandoning its original mission to support their work. Last month, after independent reviewers criticized NCAR's management, the National Science Foundation (NSF) warned its overseers that it must change to preserve its relationship with the science agency.

At a meeting on 19 June, the NSF's National Science Board approved an agency decision to extend for one year rather than the usual five the contract with the University Consortium for Atmospheric Research (UCAR) to manage NCAR. NSF said the shorter extension resulted from questions raised during its most recent peer review of the centre.

Theoretically, NSF could 'recompete' the NCAR contract and choose a single company or university rather than UCAR's consortium of 59 universities. But most observers believe that the NSF intends its decision to be a statement to UCAR that it has stepped on the toes of too many university researchers and a suggestion that NCAR should grow more slowly.

On 19 June, Eugene Beierly, director of the NSF division of atmospheric sciences, wrote to Richard Anthes, UCAR president, to say that NSF and its peer reviewers had five major concerns: UCAR's management of NCAR, UCAR's reviews of NCAR's science, NCAR's funding from non-NSF sources, its plans for growth and the attention NCAR is paying to shared facilities, such as supercomputers and airplanes.

NSF did not release accompanying documents that elaborate on these issues. Nevertheless, UCAR officials and independent scientists familiar with the situation say that the letter reflects a growing unhappiness among university researchers over the following issues:

L Non-NSF funding: Since 1982, the proportion of NCAR's funding derived from sources other than the NSF has doubled, to a third of the total. UCAR officials say that Erich Bloch, the former NSF director, encouraged them to seek outside funding. But NCAR's success places it in direct competition with university researchers who vie for the same grants, and these scientists have made their displeasure known through direct complaints and barbed peer-review evaluation. "There's real resentment out here", says one academic scientist. "When NCAR competes for grant money, they're taking money out of the pockets of academic institutions."

Wayne Shiver, assistant to UCAR's
Anthes, says that "NCAR is doing what it was encouraged under one administration to do. Now, under a new administration, we're hearing something different."

L Facilities: NCAR was created more than 30 years ago mainly to provide a central resource for academic researchers who could not afford costly equipment such as

\section{NCAR's growth}

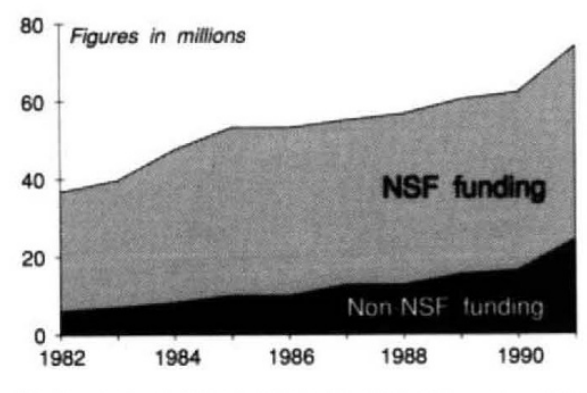

supercomputers and airplanes. Now that NCAR has its own thriving in-house research programme, outside researchers are concerned that it is not paying enough attention to shared facilities. With too little supercomputer time to go around, some atmospheric scientists want NCAR to put its money into new machines rather than its own research.

Shiver says that NCAR could never spend enough on facilities to satisfy all its users. Another supercomputer, for example, would cost an additional \$15 million a year, which "is simply not in our budget". But NCAR officials are aware of the problem, and the centre has promised to spend whatever additional money it receives for 1993 on facilities rather than on research.

L Growth: Thanks in part to the rapid growth of both the NSF budget and the federal effort on climate change research, NCAR's budget has more than doubled during the past decade. Officials were concerned that such continued expansion would further strengthen NCAR's ability to compete for outside funding, which many nonNCAR researchers already see as a threat. They also feared that NCAR would forget about its core mission to support academic atmospheric researchers.

To address some of the criticism, UCAR intends to have teams from its member universities review specific programmes at NCAR and, possibly, ask NSF to help it select the reviewers and observe the process. "Initially the reaction was Oh God, the oneyear extension sends a bad signal", says Shiver. "But now there's a welcoming of the opportunity to resolve the issue."

Many researchers believe that NCAR needs more than fine-tuning. Some would like to see a number of regional centres, rather than one national facility. Others would like NSF to fund only the shared NCAR facilities, and let its researchers compete alongside their university colleagues. Says one researcher: "it may be time for NCAR, after 30 years of being nurtured, to stand on its own two feet".

Christopher Anderson

\section{NEWS IN BRIEF}

Washington. New rules that ease the tax burden on US high-technology companies with foreign operations were announced last week by the Internal Revenue Service (IRS). The change allows companies to deduct 64 per cent of their domestic research expenses, with the rest being taxed as if they were incurred abroad. US companies have lobbied hard for a change in the rule, adopted in the late 1970 s to deal with the growing number of US companies with foreign operations. The rule turned out to be a disincentive for US-based research efforts, however, and a moratorium has blocked its implementation for most of the past 15 years. "We believe that the Bush administration has taken a giant step toward resolving a problem that has plagued America's research community for nearly two decades", says Roland Schmitt, chairman of the Council on Research and Technology, a coalition of universities, high-technology companies and trade associations that has worked to change the rule.
Washington. The US Congress failed last week to overturn a veto by President George Bush of a bill to end the ban on federally funded fetal tissue research. The 271:156 vote in the House of Representatives fell 14 votes short of the two-thirds majority required to override a presidential veto. But in an attempt to maintain pressure on the administration, Representative Henry Waxman (Democrat, California) on the same day introduced a bill that would require federally funded researchers hoping to do fetal tissue transplant research to apply to a bank that will collect tissue from ectopic pregnancies and spontaneous miscarriages. The bank was created last month after an executive order by the president. Under Waxman's bill, researchers would be free to seek the tissue from other sources if the tissue in the bank was not available or suitable. Waxman doubts that tissue from such sources other than abortion will meet the needs of researchers, but he believes that the only way to prove that point is to let the bank fail. 